\title{
Synchronous breast cancer and lymphoma: a case series and a review of the literature
}

\author{
Katharine E Cuff, ${ }^{1}$ Andrew J Dettrick, ${ }^{2}$ Boris Chern ${ }^{3}$
}

${ }^{1}$ Royal Brisbane Hospital, Butterfield Street, Herston, Queensland, Australia ${ }^{2}$ Department of Pathology, The Prince Charles Hospital, Australia

${ }^{3}$ Department of Medical Oncology, Redcliffe Hospital, Redcliffe, Australia

\section{Correspondence to} Dr Katharine E Cuff, Royal Brisbane Hospital, Butterfield Street, Herston, Old 4029, Australia;

katharine_cuff@health.gld.gov.

Accepted 9 November 2009

Published Online First

3 April 2010

\section{ABSTRACT}

Four patients with synchronous breast cancer and lymphoma are described. In all cases, the lymphoma was an unexpected finding in the histopathology of the axillary lymph-node dissection. The diagnosis of synchronous malignancies poses challenges for both the diagnosing pathologist and the treating clinicican.

The four patients described had an unexpected synchronous malignancy diagnosed during the workup for their breast cancer. It is a well-documented fact that patients with one treated malignancy are at an increased risk of developing a second tumour. However, the synchronous presentation of two malignancies is rare. In an autopsy study of 1870 known cancer deaths, 68 cases (3.6\%) had multiple primaries, and only $15(0.8 \%)$ of these were synchronous. ${ }^{1}$

We describe four patients who all presented within a 10-month time period to a regional hospital in Queensland Australia (table 1). This hospital treats on average 200 new breast cancer cases each year. To the best of our knowledge, this is the largest such case series in the English language literature, and it is remarkable considering the short time period over which the patients presented. Cox et al ${ }^{2}$ published a case series describing three patients who presented over a period of 15 years with breast carcinomas and coincidental axillary lymphoma, and there have been a number of similar single case reports. ${ }^{3-5}$

Factors that have been suggested as contributing to the development of synchronous malignancies include advanced age of the patient, primary or cancer-related immunological impairment and genetic predisposition to cancer. ${ }^{6}$ As our population ages, this is likely to become a more frequent occurrence. The UK population is predicted to reach 65 million by 2016. In 2006, there were 4.7 million people in the UK aged 75 and over. The number is projected to increase to 5.5 million by 2016 and to 8.2 million by 2031, a rise of $76 \%$ over 25 years.

Two of the four patients described had both the breast cancer and the lymphoma occurring in the same lymph node. This has been rarely described in the literature. Possible explanations have been put forward to explain why this is an unusual finding, including the fact that the lymphoma may obliterate the lymphatic channels if it occurs first, ${ }^{6}$ or may lead to a local reduction in cytokine induced adhesion of breast cancer cells to the axillary lymph nodes. ${ }^{7}$ This situation could potentially impact on both staging and prognosis of the patient. Benoit et al describe a patient with breast cancer and negative sentinel lymph nodes. ${ }^{8}$ Complete level I/II axillary lymph node dissection diagnosed low-grade lymphoma. Metastatic breast carcinoma was found in one non-sentinel node which was free from lymphoma. Sentinel lymph-node biopsy alone would have led to incorrect staging and therefore potentially inadequate treatment of the breast cancer. As our two patients with lymph-node involvement had a clinically palpable lymphadenopathy, they progressed directly to axillary dissection, and their sentinel nodes were not identified. Therefore, we are unable to comment on whether they would have had negative sentinel nodes.

Patients with lymphoma tend to be chronically immunosuppressed. As well as predisposing them to the initial development of a second malignancy, it may also impact on its behaviour. Squamous-cell carcinoma has been noted to have an increased risk of metastasis and mortality in patients with chronic lymphocytic leukaemia. ${ }^{\text {"This }}$ more aggressive behaviour has been attributed to the patient's immunosuppresed state, and it is possible that breast cancer may behave similarly.

An important point highlighted by these cases is that, in the situation of obvious axillary lymphadenopathy and an impalpable breast primary, this does not always indicate metastatic disease. The clinician needs to maintain a high index of suspicion about the possibility of synchronous malignancies, and a biopsy from both breast and axilla may be required prior to planning surgery (table 1).

Synchronous malignancies pose both a diagnostic challenge to the pathologist and a management challenge to the clinician. If a patient has a negative sentinel node biopsy for carcinoma but is diagnosed as having an unexpected lymphoma, the possibility of a completion axillary dissection should be discussed, as this may impact on staging of the breast carcinoma. Also, a decision will need to be made regarding which malignancy should 
Table 1 Case descriptions

\begin{tabular}{|c|c|c|c|c|}
\hline & Case 1 & Case 2 & Case 3 & Case 4 \\
\hline Case description & $\begin{array}{l}\text { 74-year-old: self-detected } \\
\text { right-sided breast lumps }\end{array}$ & $\begin{array}{l}\text { 74-year-old: mammographically } \\
\text { detected left breast lesion }\end{array}$ & $\begin{array}{l}\text { 79-year-old: mammographically } \\
\text { detected right breast mass and } \\
\text { axillary lymphadenopathy }\end{array}$ & $\begin{array}{l}\text { 54-year-old with a mammographically } \\
\text { detected left breast lesion }\end{array}$ \\
\hline Examination findings & $\begin{array}{l}\text { Multiple hard mobile right } \\
\text { axillary lymph nodes }\end{array}$ & NAD & $\begin{array}{l}\text { Obvious large mobile mass within } \\
\text { the right axilla; no other regional } \\
\text { lymphadenopathy detected; no } \\
\text { palpable masses within the breast }\end{array}$ & $\begin{array}{l}\text { Impalpable breast lesion, clinically } \\
\text { obvious axillary lymphadenopathy }\end{array}$ \\
\hline Surgery & $\begin{array}{l}\text { Modified radical right mastectomy } \\
\text { with level } 2 \text { axillary lymph node } \\
\text { dissection }\end{array}$ & $\begin{array}{l}\text { Wide local excision and sentinel } \\
\text { node biopsy }\end{array}$ & $\begin{array}{l}\text { Modified radical right mastectomy } \\
\text { with axillary mass excised in } \\
\text { continuity with the whole breast }\end{array}$ & $\begin{array}{l}\text { Wide local excision and axillary } \\
\text { node dissection }\end{array}$ \\
\hline $\begin{array}{l}\text { Breast-cancer } \\
\text { histopathology }\end{array}$ & $\begin{array}{l}\text { Multicentric invasive ductal breast } \\
\text { carcinoma with two identified } \\
\text { tumours. Tumour } 1 \text { was } 30 \mathrm{~mm} \text {, grade } \\
2 \text { (figure 1) and tumour } 2 \\
\text { was } 25 \mathrm{~mm} \text {, grade } 3 \text {; both } \\
\text { tumours were oestrogen receptor } \\
\text { and Her-2 CISH positive }\end{array}$ & $\begin{array}{l}17 \mathrm{~mm} \text {, grade two, invasive lobular } \\
\text { breast carcinoma oestrogen and } \\
\text { progesterone receptor positive; } \\
\text { Her-2 negative }\end{array}$ & $\begin{array}{l}\text { No evidence of carcinoma within the } \\
\text { breast tissue and it was presumed } \\
\text { that the entire lesion had been } \\
\text { removed during the core biopsy }\end{array}$ & $\begin{array}{l}16 \mathrm{~mm} \text {, grade 2, invasive ductal } \\
\text { carcinoma; the carcinoma stained } \\
\text { positive for both oestrogen and } \\
\text { progesterone receptors and } \\
\text { negative for Her-2 }\end{array}$ \\
\hline $\begin{array}{l}\text { Axillary lymph-node } \\
\text { histopathology }\end{array}$ & $\begin{array}{l}\text { Metastatic ductal carcinoma was } \\
\text { identified in } 2 \text { of the } 10 \text { nodes with } \\
\text { extranodal spread in one; the } \\
\text { remainder of the lymph nodes were } \\
\text { involved by small lymphocytic } \\
\text { lymphoma (figure 2); } \\
\text { immunohistochemical profile of } \\
\text { the infiltrate was positive for CD5, } \\
\text { CD19 and CD20; lambda light } \\
\text { chain and CD23 were weakly } \\
\text { positive consistent with chronic } \\
\text { lymphocytic leukaemia which } \\
\text { represents the same disease } \\
\text { process }\end{array}$ & $\begin{array}{l}\text { No evidence of metastatic breast } \\
\text { carcinoma in sentinel node however } \\
\text { there were features suggesting } \\
\text { low-grade B cell lymphoma; further } \\
\text { immunoperoxidase stains were } \\
\text { positive for B cell antigens CD } 10 \\
\text { and CD } 20 \text { as well as strongly } \\
\text { positive for bcl } 2 \text { protein, } \\
\text { consistent with a diagnosis of } \\
\text { grade } 1 \text { follicular B cell lymphoma }\end{array}$ & $\begin{array}{l}\text { Twenty-one lymph nodes identified; } \\
\text { the majority were partially replaced } \\
\text { with a mixed infiltrate including } \\
\text { eosinophils, plasma cells and large } \\
\text { atypical cells with the occasional } \\
\text { Reed Sternberg cell; the large cells } \\
\text { stained positive for CD } 15 \text { and CD } \\
30 \text { and negative for leucocyte } \\
\text { common antigen CD } 45 \text {; the final } \\
\text { WHO classification was classical } \\
\text { Hodgkin lymphoma }\end{array}$ & $\begin{array}{l}\text { Two lymph nodes were involved } \\
\text { with metastatic carcinoma; } \\
\text { otherwise the lymph nodes were } \\
\text { noted to be abnormally enlarged } \\
\text { and the architecture was effaced } \\
\text { by a mixed population of small } \\
\text { and large lymphoid cells; further } \\
\text { stains were positive for CD } 20 \text { and } \\
\text { CD 23, and negative for CD } 10 \text { in } \\
\text { keeping with the diagnosis of small } \\
\text { lymphocytic B cell lymphoma }\end{array}$ \\
\hline Management & $\begin{array}{l}\text { Multimodal treatment for the high } \\
\text { risk breast cancer was recommended } \\
\text { including chemotherapy, radiation, } \\
\text { traztuzumab and hormonal therapy; } \\
\text { haematology workup diagnosed CLL } \\
\text { Rai Stage 0; the patient is being } \\
\text { observed }\end{array}$ & $\begin{array}{l}\text { Absolute benefit of chemotherapy } \\
\text { was estimated at less than } 2 \% \\
\text { and therefore was not recommended; } \\
\text { the patient underwent } 6 \text { weeks of } \\
\text { adjuvant radiotherapy followed by } \\
\text { an aromatase inhibitor; haematology } \\
\text { workup involved staging with PET } \\
\text { and BMAT and the decision to adopt } \\
\text { a watchful wait approach was made, } \\
\text { given the low-grade nature of the } \\
\text { lymphoma }\end{array}$ & $\begin{array}{l}\text { The patient's stage } 1 \text { breast cancer } \\
\text { was treated with hormonal therapy } \\
\text { alone; after haematological workup, } \\
\text { her Hodgkin lymphoma was } \\
\text { classified as a stage } 1 \mathrm{~A} \text { and } \\
\text { local irradiation was chosen as } \\
\text { initial treatment }\end{array}$ & $\begin{array}{l}\text { A staging CT demonstrated } \\
\text { widespread lymphadenopathy from } \\
\text { the base of the neck to the pelvis; } \\
\text { the decision was made to treat the } \\
\text { lymphoma as a priority; this patient } \\
\text { also required radiation treatment to } \\
\text { the breast and axilla as well as further } \\
\text { chemotherapy for stage IIA breast } \\
\text { carcinoma followed by hormonal } \\
\text { treatment }\end{array}$ \\
\hline
\end{tabular}

BMAT, bone marrow aspirate and trephine; $\mathrm{CISH}$, chromogenic in situ hydridization; Her-2, Human epidermal growth factor receptor 2; NAD, no abnormalities detected.

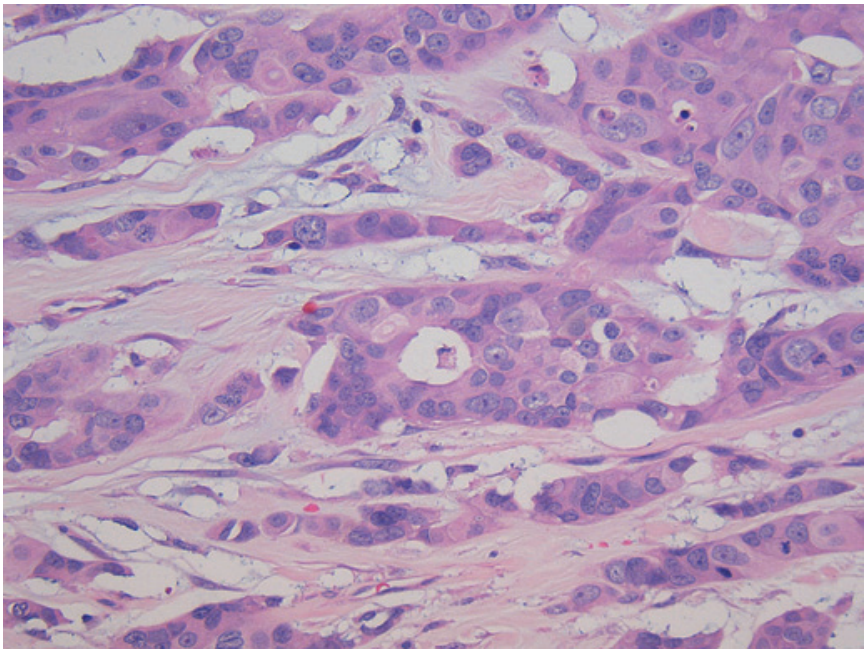

Figure 1 Mastectomy specimen showing grade 2 invasive ductal carcinoma (H\&E, original magnification $\times 200)$.

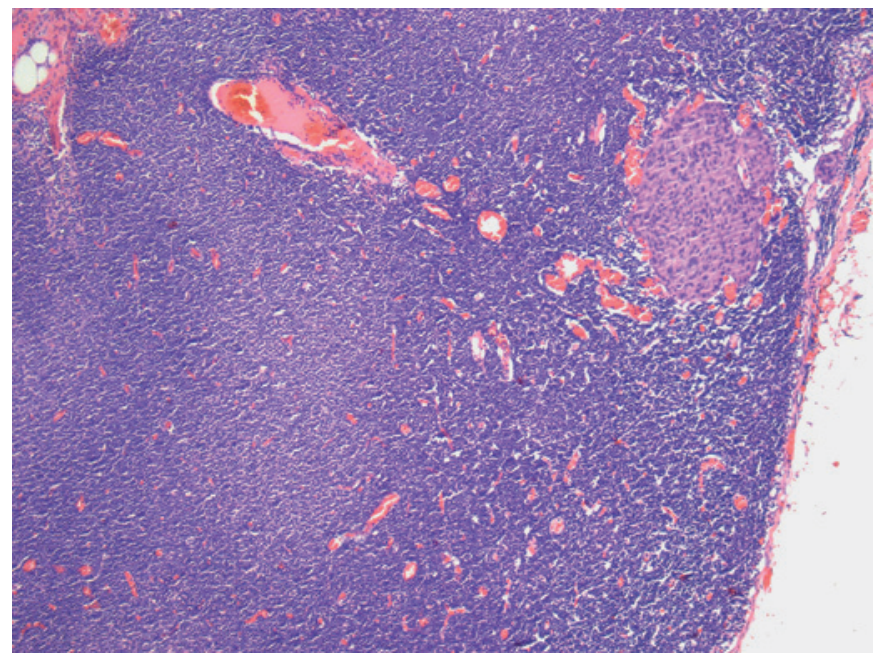

Figure 2 Axillary lymph node specimen showing effacement of the normal architecture by a monotonous population of small malignant lymphocytes. A 'proliferation centre' (pale zone) which is characteristic of small lymphocytic lymphoma can be seen to the left. A microscopic metastatic deposit of breast carcinoma can be seen to the right, under the capsule (H\&E, original magnification $\times 40$ ). 


\section{Take-home messages}

- Synchronous malignancies are rare, but an ageing population may make them a more frequent occurrence.

- Patients with low-grade lymphomas are susceptible to developing a second malignancy, and thus their pathological specimens require careful examination.

- In the situation of an impalpable breast cancer with palpable axillary lymphadenopathy, it cannot be assumed that the patient has metastatic breast cancer; biopsy of both the breast lesion and axillary nodes may be indicated.

take priority with treatment, and thorough staging investigations will need to be performed for both primaries.

\section{Competing interests None}

Patient consent Obtained.

Provenance and peer review Not commissioned; externally peer reviewed.

\section{REFERENCES}

1. Lee TK, Myers RT, Scharyj M, et al. Multiple primary malignant tumours (MPMT) study of 68 autopsy cases (1963-1980). J Am Geriatr Soc 1982;30:744-53.

2. Cox J, Lunt L, Webb L. Synchronous presentation of breast carcinoma and lymphoma in the axillary nodes. Breast 2006;15:246-52.

3. Barranger E, Marpeau 0, Uzan S. Axillary sentinel node involvement by breast cancer coexisting with B-cell follicular lymphoma in nonsentinel nodes. [letter]. Breast J 2005;11:227-8

4. Roy SD, Stafford JA, Scally J, et al. A rare case of breast carcinoma co-existing with axillary mantle cell lymphoma. World J Surg Oncol 2003;1:1-3.

5. Khalbuss WE, Fischer G, Ahmad M, et al. Synchronous presentation of breast carcinoma with plasmacytoid cytomorphology and multiple myeloma. Breast J 2006;12:165-7.

6. Ambrosiani L, Bellone S, Declich P, et al. Breast carcinoma metastatic to a lymphoma: report of a case with review of literature. Histopathology 1999; 34:87-9.

7. Mannel DN, Orosz P, Hafner M, et al. Mechanisms involved in metastasis enhanced by inflammatory mediators. Circ Shock 1994;44:9-13.

8. Benoit L, Arnould L, Colllin F, et al. Concurrent lymphoma and metastatic breast carcinoma in the axillary, confounding sentinel lymph-node biopsy. Eur J Surg Oncol 2004;30:462-3.

9. Mehrany $\mathbf{K}$, Weenig $\mathrm{RH}$, Lee $\mathrm{KK}$, et al. Increased metastasis and mortality from cutaneous squamous cell carcinoma in patients with chronic lymphocytic leukemia. J Am Acad Dermatol 2005;53:1067-71. 